\title{
PERBANDINGAN UPAYA PELEMAHAN TERHADAP LEMBAGA ANTIKORUPSI KPK INDONESIA DAN ICAC HONG KONG
}

\author{
Narendro Setyo Pratomo Baskoro, Sri Budi Eko Wardhani \\ Departemen Ilmu Politik, Universitas Indonesia \\ Email: narendrosetyo.ui@gmail.com
}

\begin{abstract}
Abstrak
Berdirinya lembaga antikorupsi di beberapa negara tidak menjamin bahwa setiap negara dapat sepenuhnya bebas dari korupsi, bahkan upaya pelemahan lembaga antikorupsi seperti di KPK Indonesia dan ICAC Hong Kong pernah dan masih terus terjadi sampai dengan beberapa tahun ke belakang. Penelitian ini bertujuan untuk meneliti bagaimana upaya pelemahan tersebut dilakukan, serta faktor yang menyebabkan terjadinya upaya pelemahan terhadap kedua lembaga antikorupsi tersebut. Dalam penelitian ini menggunakan metode kualitatif yang teknik pengumpulan datanya diperoleh dari dokumentasi dan dari hasil wawancara dengan pihak-pihak yang berkaitan dengan penelitian ini. Hasil dari penelitian ini menemukan bahwa upaya pelemahan terhadap lembaga antikorupsi dilakukan dengan bermacam-macam cara yaitu jika di KPK Indonesia melalui cara regulasi seperti adanya revisi undang-undang KPK tahun 2019 yang masih menjadi perdebatan dan kontroversi di masyarakat luas, kemudian cara lainnya melalui kriminalisasi dan teror kepada komisioner maupun pegawai KPK oleh pihakpihak yang tidak senang dengan keberadaan lembaga antikorupsi KPK. Jika di ICAC Hong Kong hal tersebut justru banyak terjadi dari internal lembaga itu sendiri seperti beberapa kasus yang menyeret pegawai serta komisioner ICAC dan sempat berakibat pada terganggunya kinerja ICAC dalam menangangi kasus korupsi. Upaya pelemahan terhadap lembaga antikorupsi dapat dihindari jika adanya political will dari semua pihak terutama Kepala Negara dengan tetap konsisten mendukung penuh pemberantasan korupsi serta bertindak tegas terhadap siapapun yang berusaha melakukan upaya pelemahan terhadap lembaga antikorupsi.
\end{abstract}

Kata Kunci: Pelemahan; Lembaga Antikorupsi; KPK; ICAC Hong Kong.

\section{Abstract}

The establishment of anti-corruption institutions in several countries does not guarantee that every country can be completely free from corruption, even efforts to weaken anti-corruption institutions such as the Indonesian KPK and Hong Kong ICAC have been and are still happening for the past few years. This study aims to examine how the weakening efforts were carried out, as well as the factors that led to the weakening of the two anti-corruption institutions. In this study using qualitative methods, the data collection techniques were obtained from documentation and from interviews with parties related to this research. The results of this study found that efforts to weaken anti-corruption institutions were 
carried out in various ways, namely if at the Indonesian KPK through regulatory means such as the revision of the 2019 KPK law which is still a matter of debate and controversy in the wider community, then another way is through criminalization and terror against KPK commissioners and employees by parties who are not happy with the existence of the KPK anti-corruption agency. At ICAC Hong Kong, this actually happened a lot from within the institution itself, such as several cases that dragged ICAC employees and commissioners and had resulted in the disruption of ICAC's performance in dealing with corruption cases. Efforts to weaken anti-corruption institutions can be avoided if there is political will from all parties, especially the Head of State, while consistently fully supporting the eradication of corruption and taking firm action against anyone who tries to weaken anti-corruption institutions.

Keywords: Weakening; Anti-Corruption Agency; KPK; ICAC Hong Kong

Diterima: 10-12-2021

Direvisi: 12-01-2022

Diterbitkan: 20-01-2022

\section{Pendahuluan}

Di awal era reformasi, Indonesia menghadapi salah satu persoalan krusial yang harus segera diselesaikan yaitu korupsi, jika dilihat dalam kehidupan sehari-hari korupsi hampir terjadi di setiap tingkatan dan aspek kehidupan masyarakat. Tanpa disadari korupsi muncul dari kebiasaan yang dianggap lumrah serta wajar oleh masyarakat umum seperti memberikan uang atau hadiah kepada pejabat atau keluarganya sebagai imbal jasa atas pelayanan yang kemudian hal tersebut menjadi bibit-bibit korupsi yang nyata di dalam kehidupan masyarakat (KPK, 2006). Korupsi telah sedemikian rupa berlangsung dalam masyarakat secara meluas, sehingga dirasakan telah melanggar hak-hak sosial dan ekonomi masyarakat sebagai bagian dari Hak Asas Manusia (Danil, 2012).

Selain adanya institusi Kepolisian dan Kejaksaaan yang telah mempunyai tugas menangani kasus korupsi, diperlukan pula lembaga yang secara khusus menangangi pemberantasan korupsi di Indonesia. Dibentuk berdasarkan Undang-Undang Nomor 30 Tahun 2002 tentang Komisi Pemberantasan Tindak Pidana Korupsi, hadirnya Komisi Pemberantasan Korupsi (KPK) sebagai lembaga negara yang bersifat independen dan dalam melaksanakan tugas serta wewenangnya bebas dari kekuasaan manapun, diharapkan dapat menjadi jawaban atas segala keresahan mengenai pemberantasan korupsi di Indonesia. KPK dibentuk bukan untuk mengambil alih tugas pemberantasan korupsi dari institusi-institusi yang telah ada sebelumnya, namun peran KPK sebagai trigger mechanism yang berarti mendorong atau sebagai stimulus agar pemberantasan korupsi menjadi lebih efektif.

Program pemberantasan korupsi yang mengandalkan pada penegakan hukum, pengawasan oleh media dan kelompok masyarakat sipil dianggap kurang membuahkan hasil yang diharapkan karena pemberantasan korupsi dari dalam lembaga pemerintah terkadang justru tidak mendapat perhatian padahal korupsi banyak terjadi di dalam birokrasi pemerintah itu sendiri dan dari banyak kasus 
pemberantasan korupsi justru gagal karena melibatkan pemimpin politik (Widoyoko, 2016).

Dalam perjalanan memberantas korupsi yang dilakukan oleh KPK pun tidak sepenuhnya mendapat dukungan, berbagai cara dilakukan untuk melemahkan kinerja KPK oleh pihak-pihak yang kepentingannya terganggu oleh kehadiran KPK. Adnan Topan Husodo, koordinator Indonesia Corruption Watch (ICW) menyatakan bahwa perang melawan korupsi di Indonesia sering berhenti karena nafas kemauan politik yang tak cukup panjang, KPK dipandang sebagai ancaman serius yang dibuktikan kemudian dengan berbagai upaya untuk melemahkan KPK seperti melalui Judicial Review di Mahkamah Konstitusi yang telah dilakukan beberapa kali oleh pihak yang berbeda, kemudian melalui pelemahan internal KPK dalam bentuk kriminalisasi Komisioner KPK yang terjadi secara periodik (Indrayana, 2016). Transparency International Indonesia (TII) merilis Indeks Persepsi Korupsi (IPK) Indonesia tahun 2020 yaitu skor Indonesia berada di angka 37 pada skala 0-100 yang mana skor 0 menggambarkan sangat korup dan skor 100 sangat bersih, Wawan Suyatmiko yang merupakan Manajer Riset TII menyatakan turunnya IPK Indonesia juga berdampak pada menurunnya posisi Indonesia menjadi peringkat 102 dari 180 negara yang dinilai IPKnya yang pada tahun 2019 Indonesia berada pada skor 40 dan peringkat 85 (Ramadhan, 2021).

Terhambatnya kinerja KPK dalam memberantas korupsi disebabkan adanya upaya pelemahan KPK yang salah satunya melalui kasus hukum yang menjerat beberapa Komisioner KPK menjadi sorotan serta perhatian publik dan hal tersebut dianggap sebagai bentuk kriminalisasi terhadap Komisioner KPK, karena beberapa kasus hukum yang dituduhkan terhadap para Komisioner KPK merupakan kasus lama yang telah terjadi sebelum yang bersangkutan dilantik sebagai Komisioner KPK. Wakil Ketua KPK periode 2011 - 2015 menyatakan bahwa ada pihak-pihak tertentu yang tidak suka jika koruptor ke penjara dan juga adanya hambatan yang semakin merajalela untuk menggiring pejabat korup di level teratas yang kemudian ada juga yang ingin melakukan kriminalisasi kepada para Komisioner KPK sebagai rekayasa untuk melemahkan dan menjatuhkan lembaga KPK (Iskandar, 2015). Upaya pelemahan lain dalam bentuk regulasi yaitu melalui Revisi Undang-Undang KPK (RUU KPK), beberapa pasal di dalamnya dianggap dapat mengurangi independensi KPK dalam memberantas korupsi. Pada tahun 2012, tahun 2015 dan tahun 2017 RUU KPK sempat beberapa kali akan dibahas dan beberapa kali pula ditunda namun pada tahun 2019 akhirnya RUU KPK resmi disahkan menjadi Undang-Undang Nomor 19 Tahun 2019 tentang Perubahan kedua atas Undang-Undang Nomor 30 Tahun 2002 tentang Komisi Pemberantasan Tindak Pidana Korupsi.

Tidak hanya Indonesia yang memiliki lembaga antikorupsi, beberapa negara juga memiliki lembaga yang bertanggung jawab dalam pemberantasan korupsi, salah satu lembaga antikorupsi yang terkenal dan menjadi contoh bagi negara-negara lain termasuk Indonesia yaitu Independent Commission Against Corruption (ICAC) Hong Kong. Pada tahun 1960 - 1970an Hong Kong mengalami kemajuan pesat dalam sektor pembangunan, bukan hanya berdampak positif bagi kesejahteraan masyarakat tetapi juga menjadi celah 
korupsi bagi petugas dan pejabat pemerintah dalam memberikan pelayanan. Korupsi yang merajalela saat itu dimana menawarkan uang suap kepada pejabat pemerintah dianggap wajar, walaupun Hong Kong telah memiliki penegak hukum yang fokus menangani tindak pidana korupsi dibawah Kepolisian Hong Kong namun upaya pemberantasan korupsi tidak berjalan efektif karena korupsi paling banyak justru terjadi di Kepolisian Hong Kong. Seperti diketahui bahwa Hong Kong merupakan tempat transit para pengedar narkotika yang kemudian berkolusi dengan petugas kepolisian dan akibatnya petugas kepolisian yang korup melindungi para pelaku narkotika tersebut. Setiap hari petugas kepolisian menerima setoran dari pelaku / sindikat narkotika sejumlah 10.000 dolar Hong Kong dan kemudian uang tersebut dibagi-bagi dari atas ke bawah di tubuh kepolisian secara hierarkis (Hamzah, 2008).

Peristiwa lainnya di Hong Kong yaitu petugas ambulance baru mau menjemput pasien apabila sudah menerima uang atau "tips", lalu pasien di rumah sakit pun perlu "menyogok" petugas dahulu untuk mendapatkan kamar perawatan, dan ada juga petugas pemadam kebakaran baru mau melakukan pemadaman api jika sudah menerima uang sebagai imbalan (Eryanto, 2019). Selain karena beberapa peristiwa tersebut diatas, salah satu pemicu terbesar lahirnya lembaga antikorupsi di Hong Kong yaitu kasus korupsi Peter Godber yang merupakan seorang Kepala Kepolisian yang pada tahun 1973 diselidiki karena memiliki kekayaan lebih dari 4.300.000 (empat juga tigas ratuh ribu) dolar Hong Kong yang diperoleh dari hasi korupsi namun saat itu Peter Godber berhasil melarikan diri dari Hong Kong dan hal itu memicu kemarahan besar masyarakat karena pemerintah dianggap gagal mengatasi pemberantasan korupsi (Manion, 2004). Sir Alastair Blair Kerr, seorang Hakim Senior ditunjuk oleh pemerintah guna membentuk tim penyelidikan terkait pelarian Peter Godber dan ia menyatakan bahwa badan-badan yang bertanggung jawab merasa masyarakat tidak akan pernah yakin kepada pemerintah yang berniat memberantas korupsi kecuali dengan membentuk badan pemberantasan koruspi yang terpisah dari kepolisian, hal tersebut kemudian yang membuat berdirinya ICAC Hong Kong pada Februari 1974.

Seperti halnya KPK Indonesia, dalam perjalanannya ICAC Hong Kong yang berdiri lebih dahulu dari KPK Indonesia pun mengalami beberapa upaya pelemahan. Teror terhadap ICAC Hong Kong pernah terjadi khususnya di awal-awal menjalankan tugasnya pada tahun 1974, berbagai ancaman datang dari koruptor (khususnya para polisi korup) secara terus-menerus pada para pegawai ICAC Hong Kong yang semuanya terdiri atas anak-anak muda yang belum berpengalaman. Bahkan akibat dari teror yang menyasar para pegawai ICAC Hong Kong tersebut, ada beberapa pegawai yang tidak tahan sampai menderita gangguan jiwa dan beberapa diantaranya memilih mengundurkan diri (Susanto dan Muttaqin, 2018). Selanjutnya pada tahun 1977, ICAC Hong Kong telah menangkap 247 koruptor dimana 143 diantaranya adalah polisi, hal tersebut membuat para polisi kembali melakukan perlawanan terhadap ICAC Hong Kong dengan berkumpul di depan kantor ICAC Hong Kong lalu memaksa masuk ke dalam hingga menyebabkan sebagian petugas ICAC Hong Kong yang menahan pun terluka (Harymurti, 2012). 
Berdasarkan uraian diatas, penulis mengambil tema tersebut guna dilakukan penelitian yang lebih mendalam serta menganalisa sejauh mana upaya pelemahan terhadap lembaga antikorupsi KPK Indonesia dan ICAC Hong Kong. Penelitian ini juga mempunyai tujuan untuk meneliti bagaimana upaya pelemahan tersebut terjadi dan faktor apa saja yang menyebabkan terjadinya upaya pelemahan terhadap kedua lembaga antikorupsi tersebut.

\section{Metode Penelitian}

Metode penelitian yang digunakan dalam penelitian ini adalah metode kualitatif. Metode kualitatif memiliki pendekatan yang lebih beragam dalam penelitian akademis dibandingkan metode kuantitatif (Creswell, 2014). Dalam hal teknik pengumpulan data, penulis membagi menjadi dua bagian : Pertama yaitu Dokumentasi, melalui dokumendokumen kualitatif penulis mengumpulkan data-data yang berkaitan dengan penelitian yang sumbernya dapat berasal dari buku-buku, artikel, jurnal, skripsi, tesis, disertasi, surat kabar (cetak maupun elektronik) dan data-data penunjang lainnya yang berkaitan dengan penelitian penulis. Kedua yaitu Wawancara, dalam hal ini penulis melakukan wawancara baik secara langsung maupun secara daring dengan berbagai pihak yang memiliki informasi terkait dengan penelitian yang sedang penulis teliti, beberapa diantaranya yaitu perwakilan dari Komisioner KPK periode 2015 - 2019 dan Indonesia Corruption Watch (ICW).

\section{Hasil dan Pembahasan}

\section{Upaya Pelemahan Terhadap Komisi Pemberantasan Korupsi (KPK) Indonesia}

Sejak awal berdiri sampai dengan tahun 2019 telah terjadi 4 (empat) kali pergantian Komisioner KPK, namun hal tersebut tidak serta merta membuat kasus korupsi di Indonesia menjadi hilang. Banyaknya kasus korupsi yang terus bermunculan membuat KPK tidak menyerah begitu saja dalam menjalankan tugasnya sebagai lembaga antikorupsi, namun di sisi lain tidak dapat dipungkiri bahwa terdapat banyak rintangan serta upaya pelemahan yang menerpa KPK dalam memberantas korupsi. Dalam hal ini KPK tidak sekedar dibuat tak berfungsi namun juga dihabisi secara sistematis sampai berulang-ulang dimana KPK digambarkan sebagai tempat beroperasinya gerakan radikal dengan cap taliban, lalu para Komisionernya di kriminalisasi dan dicari kesalahannya oleh kekuasaan yang bersekutu dengan lembaga penegak hukum lainnya (Widjojanto, 2020).

Bentuk-bentuk upaya pelemahan terhadap KPK dapat dikategorikan menjadi 2 (dua) bagian yaitu melalui cara regulasi seperti adanya upaya pembahasan serta pengesahan RUU KPK, kemudian dengan cara non regulasi berupa kriminalisasi maupun teror ditujukan untuk mengganggu kinerja Komisioner dan pegawai KPK dalam memberantas korupsi dan itu akan berdampak pada melemahnya kinerja KPK. Dalam rentang tahun 2015 - 2019 telah terjadi beberapa kali peristiwa kriminalisasi serta teror terhadap Komisioner maupun pegawai KPK, beberapa diantaranya sebagai berikut: 
1. Agus Rahardjo dan Saut Situmorang, Komisioner KPK 2015 - 2019. Pada bulan Oktober 2017 dilaporkan ke Bareskrim Polri oleh kuasa hukum Setya Novanto atas tuduhan tindak pidana membuat surat palsu dan menyalahgunakan wewenang dalam penyidikan kasus korupsi e-KTP yang menjerat Setya Novanto. Merespon hal tersebut, Saut Situmorang menyatakan bahwa pelaporan tersebut merupakan reaksi dari apa yang telah dilakukan olehnya sebagai Komisioner KPK, oleh karenanya ia siap menjalani proses hukum sesuai dengan undang-undang yang berlaku untuk memberikan bukti bahwa KPK tidak pernah main-main dalam mengungkap kasus korupsi.

"Upaya-upaya pelemahan itu kalau dari sejarah yang saya lihat sejak KPK berdiri itu sudah ada, kemudian saat kita masuk sebagai Komisioner KPK itu ada kasus e-KTP lalu ada upaya macam-macam dari parlemen ketika itu diantaranya upaya-upaya yang kaitannya dengan angket segala macam." (Wawancara dengan Saut Situmorang).

2. Novel Baswedan, Penyidik senior KPK. Pada bulan April 2017 mendapatkan serangan fisik berupa penyiraman air keras oleh orang tak dikenal di dekat rumahnya di kawasan Kelapa Gading Jakarta. Hal tersebut terjadi saat Novel Baswedan hendak pulang ke rumah seusai melaksanakan sholat subuh di Masjid dekat rumahnya, serangan air keras itu diarahkan ke bagian wajah dan tepat mengenai matanya yang kemudian berdampak pada salah satu matanya tidak dapat berfungsi dengan normal sampai dengan saat ini.

"Seperti Novel yang disiram air keras, ada beberapa penyidik di teror pernah juga kendaraannya disiram air keras dan banyak lagi yang lain, terus misalnya lagi melakukan penyelidikan lalu ditangkap oleh aparat. Hal-hal seperti itu banyak terjadi, cuma kita tidak dimasukan ke media dan itu ancaman yang secara fisik jadi mungkin mereka yang tidak suka dengan KPK ingin melihat KPK itu untuk tidak independen dan tidak melakukan upaya-upaya pemberantasan korupsi." (Wawancara dengan Laode M. Syarif).

3. Laode M. Syarif dan Agus Rahardjo, Komisioner KPK 2015 - 2019. Pada bulan Januari 2019, rumah kedua Komisioner KPK 2015 - 2019 tersebut mendapatkan teror berupa sebuah benda yang merupakan bom molotov. Di rumah Laode M. Syarif ditemukan sebuah benda berupa botol berisi minyak tanah beserta sumbunya, sedangkan di rumah Agus Rahardjo ditemukan sebuah benda yang digantungkan di pagar rumahnya yang merupakan bom rakitan. Kedua bom yang berada masing-masing di rumah Laode M. Syarif dan Agus Rahardjo berhasil diamankan oleh tim Densus 88 Polri.

"Jadi ancamannya itu kan banyak ya disamping ancaman fisik juga ada ancaman untuk kriminalisasi. Ancaman kriminalisasi itu terjadi sejak dua periode sebelumnya yang melibatkan Bibit Samad Rianto dan Chandra M. Hamzah, terus yang kedua terjadi ketika Abraham Samad dan Bambang Widjojanto, yang ketiga adalah ketika Pak Agus Rahardjo dan saya ketika 
rumah saya di teror dengan bom molotov dan Pak Agus Rahardjo dengan bom yang digantung di depan rumahnya." (Wawancara dengan Laode M. Syarif).

Terkait dengan terjadinya teror kepada para Komisoner maupun pegawai KPK, Laode M. Syarif menyatakan jika itu merupakan resiko dari sebuah pekerjaan apalagi dirinya dan Komisioner lainnya telah di sumpah untuk tetap menjalankan tugas sebaikbaiknya apapun resikonya. Namun demikian dirinya tidak menyangka bahwa rumahnya menjadi target teror bom molotov, yang tentu kejadian tersebut tidak hanya membahayakan bagi dirinya namun juga bagi orang-orang yang berada di rumahnya pada saat itu.

"Jadi ya saya pun sebelumnya sudah paham bahwa menjadi Komisioner KPK itu banyak tantangannya termasuk kriminalisasi dan lain-lain. Nah tapi kan kita juga tidak menyangka bahwa misalnya rumah tengah malam dilempari bom molotov untung satu tidak meledak namun yang satunya meledak, kalau yang satunya ikut meledak itu pasti terbakar mobil dan rumah. Namun sekali lagi ya itu bagian dari resiko pekerjaan karena kita sudah mengambil dan bersumpah untuk menjalankan pekerjaan itu ya kita harus jadikan pembelajaran saja." (Wawancara dengan Laode M. Syarif).

\section{Faktor Penyebab Terjadinya Upaya Pelemahan Terhadap Komisi Pemberantasan Korupsi (KPK) Indonesia}

Banyaknya upaya pelemahan terhadap KPK selama ini tentu bukan tanpa sebab, beberapa peristiwa yang telah terjadi beberapa tahun terakhir pun berdampak pada terganggunya kinerja KPK dalam menangangi kasus korupsi. Hal tersebut bisa terjadi disebabkan oleh adanya pihak-pihak yang merasa resah dengan keberadaan KPK dalam memberantas korupsi, dan juga adanya faktor balas dendam terhadap orang-orang di KPK yang telah menangkapnya.

"Saya pikir mengingat banyak sekali kasus-kasus yang diproses KPK mungkin itu adalah bentuk balas dendam, perlawanan atau corruptor fights back jadi perlawanan dari koruptor itu untuk bagaimana lembaga yang independen dan profesional ini untuk diubah sekurang-kurangnya keindependenannya." (Wawancara dengan Laode M. Syarif).

Faktor lain yang menyebabkan terjadinya upaya pelemahan terhadap KPK yaitu perilaku beberapa orang terdekat dari para Komisioner maupun pegawai KPK itu sendiri, sebagai contoh banyaknya orang suruhan dari koruptor yang mencoba mendekati orangorang di sekitar para Komisioner dengan tujuan memperoleh informasi terkait kasus yang sedang ditangani dan juga untuk mengganggu kinerja para Komisioner dalam memberantas korupsi.

"Jadi sebenarnya kalau ditanya faktor apa yang membuat pelemahan KPK itu ada ya ditengah kasus-kasus besar itu pengalaman saya, ajudan saya itu sering menerima telepon dari pihak luar yang mencoba mengintervensi kasus yang 
sedang saya tangani dan saya selalu menegur ajudan saya awas kalau masih menerima telepon dari pihak luar." (Wawancara dengan Saut Situmorang pada Oktober 2021).

Indonesia Corruption Watch (ICW) sebagai salah satu organisasi non pemerintah yang terdiri atas aktivis pegiat antikorupsi pun menyatakan bahwa salah satu faktor penyebab terjadinya upaya pelemahan lembaga antikorupsi itu karena adanya kerjasama antara aktor-aktor yang tidak senang terhadap keberadaan lembaga antikorupsi karena hal tersebut dapat mengganggu aktivitas aktor-aktor tersebut dalam menjalankan kepentingannya terkait dengan korupsi.

"Sebenarnya ini menandakan adanya satu fenomena politik yang bisa dibilang sangat dinamis dimana aktor-aktornya saling bekerjasama satu dengan lainnya dan memiliki satu kepentingan yang sama untuk kemudian mengendalikan lebih efektif upaya-upaya pemberantasan korupsi dengan cara melemahkan badan antikorupsinya." (Wawancara dengan Adnan Topan Husodo ICW).

Para pelaku korupsi bekerja terorganisir dengan berbagai macam motif baik itu keuntungan diri sendiri atau kelompoknya. Mereka juga bekerjasama dengan sesama kolega di birokrasi, partai politik, parlemen yang biasa disebut sebagai "politisi busuk" maupun pengusahan hitam yang kemudian pada titik ini tiga kekuatan bertemu secara simbiotik yaitu oligarki, kartel politik dan dinasti politik (Widjojanto, 2017).

\section{Upaya Pelemahan Terhadap Independent Commission Againts Corruption (ICAC) Hong Kong}

Sebagai salah satu lembaga antikorupsi yang dijadikan role model oleh banyak negara, perjalanan Independent Commission Against Corruption (ICAC) Hong Kong tidak sepenuhnya bebas dari hambatan maupun gangguan. Mulai dari awal dibentuk saat masih berada dibawah kolonial Inggris sampai dengan ketika Hong Kong sudah berada dibawah pemerintah China, upaya-upaya pelemahan terhadap ICAC juga kerap terjadi.

Pada tahun 1993 kasus kontroversial terjadi di internal ICAC, ditandai dengan adanya ketidakpercayaan Gubernur Hong Kong Chris Patten terhadap salah satu pegawai ICAC yang menjabat sebagai Wakil Direktur Operasi bernama Alex Tsui Ka-Kit. Pimpinan ICAC saat itu Betrand de Speville kemudian memberhentikan Alex Tsui dari jabatannya dengan menyatakan bahwa telah dilakukan penyelidikan internal ICAC dan diputuskan memberhentikan Alex Tsui yang mana hal tersebut telah sesuai dengan Undang-Undang ICAC bagian 8 (2). Alex Tsui menganggap pemecatannya itu akibat dirinya membela pegawai perempuan ICAC yang mengalami pelecehan seksual oleh atasannya bernama Michael W. Croft seorang ekspatriat Inggris, lalu Alex Tsui pun tidak teima atas pemecatannya dan kemudian melakukan kampanye ke publik terkait dengan penyalahgunaan kekuasaan yang terjadi di ICAC seperti kesalahan yang dilakukan oleh atasannya mulai dari adanya rasisme sampai dengan penyalahgunaan kekuasaan dengan 
memata-matai perusahaan asal China yang beroperasi di Hong Kong demi kepentingan pemerintah kolonial. Alex Tsui juga melaporkan ke polisi bahwa Direktur Operasi ICAC, Jim Buckle berusaha mengintervensi penyelidikan internal terhadap Michael W. Croft (Febari, 2015).

Pada tahun 2003, seorang asisten penyidik ICAC di penjara selama 9 (sembilan) bulan akibat memberikan keterangan palsu pada sidang pengadilan, hal itu disebabkan ia menyembunyikan fakta terkait dirinya yang melakukan ancaman terhadap seorang tersangka guna bekerja sama dalam penyelidikan kasus yang sedang diproses oleh ICAC (SCMP Reporter, 2003). Peristiwa selanjutnya terjadi pada tahun 2012 dimana terdapat skandal yang melibatkan Komisioner ICAC periode 2007 - 2012 yaitu Timothy Tong, saat itu diketahui bahwa ia telah menghabisan uang negara untuk hiburan, jamuan makan dan juga membeli hadiah untuk pejabat senior bidang hukum di China. Saat mengetahui hal tersebut, ICAC dipaksa menyelidiki dugaan tersebut dengan cara mengaudit keuangan yang kemudian ditunjukkannya bahwa terdapat dua jamuan makan malam yang diadakan oleh Timothy Tong melebih batas biaya yang telah ditentukan. Tidak hanya itu Timothy Tong juga diketahui membelikan hadiah yang cukup mahal kepada beberapa pejabat senior dan hal itu dilakukannya selama dirinya menjabat sebagai Komisioner ICAC, karena merasa malu dan harus bertanggung jawab atas perbuatannya maka ia pun mengundurkan diri sebagai Komisioner ICAC pada bulan Juli 2012 (SCMP Reporter, 2014).

Berbeda dengan KPK Indonesia, upaya pelemahan terhadap ICAC Hong Kong justru lebih banyak terjadi dari dalam / internal lembaga antikorupsi tersebut yang kemudian dampak dari adanya rangkaian peristiwa tersebut membuat kinerja ICAC dalam memberantas korupsi pun sempat terganggu.

\section{Faktor Penyebab Terjadinya Upaya Pelemahan Terhadap Independent Commission Againts Corruption (ICAC) Hong Kong}

Tidak jauh berbeda dengan KPK Indonesia dan lembaga antikorupsi di negara lainnya, jika berbicara mengenai faktor yang menyebabkan terjadi upaya pelemahan terhadap lembaga antikorupsi tentu diakibatkan oleh adanya pihak-pihak yang tidak senang dengan keberadaan lembaga antikorupsi.

"Sebenarnya kalau kita ngomong tentang lembaga antikorupsi independen, kasus pelemahan itu tidak hanya spesial kasus Indonesia, artinya di berbagai belahan dunia lain yang punya kebijakan membentuk badan antikorupsi independen seperti KPK di Indonesia atau ICAC di Hong Kong banyak juga yang berakhir dengan kekalahan upaya pemberantasan korupsi karena badan antikorupsi yang mulai bekerja kemudian dimatikan dengan berbagai cara." (Wawancara dengan Adnan Topan Husodo ICW).

Ketika pertama kali dibentuk pada tahun 1974 dan kemudian tahun 1977, upaya pelemahan terhadap ICAC yang dilakukan secara terang-terangan oleh koruptor khususnya polisi korup disebabkan oleh tidak terimanya para polisi korup tersebut atas 
penangkapan rekan-rekan mereka sesama polisi korup yang dilakukan oleh tim ICAC. Selanjutnya juga pada upaya pelemahan di tahun 1993 dan tahun 2003 dimana upaya pelemahan tersebut terjadi dari internal lembaga antikorupsi tersebut, hal itu disebabkan karena masih adanya beberapa pegawai ICAC yang kurang berintegritas sehingga melakukan tindakan yang melanggar aturan yang telah ditetapkan oleh ICAC. Bahkan peristiwa di tahun 2012 justru melibatkan Komisionernya langsung yang dalam hal ini seharusnya ia dapat menjadi contoh yang baik bagi pegawainya terkait dengan integritasnya dalam memimpin lembaga antikorupsi ICAC, namun yang dilakukannya justru membuat kinerja ICAC menjadi lemah dan nama baiknya pun dipertaruhkan.

\section{Kesimpulan}

Upaya pelemahan terhadap lembaga antikorupsi khususnya KPK di Indonesia dan ICAC di Hong Kong terjadi dengan berbagai macam cara. Pertama, terhadap KPK Indonesia upaya pelemahan beberapa tahun belakangan ini terjadi dengan dua cara yaitu melalui regulasi dan melalui kriminalisasi / teror. Jika dengan cara regulasi seperti adanya beberapa kali upaya pembahasan RUU KPK mulai dari tahun 2012, tahun 2015, tahun 2017 dan puncaknya pada tahun 2019 dengan disahkannya RUU KPK menjadi UU Nomor 19 Tahun 2019 yang pada saat itu sebenarnya masih menjadi kontroversi di masyarakat luas. Sedangkan jika melalui cara kriminalisasi dan teror kepada beberapa Komisionernya seperti kriminalisasi terhadap Agus Rahardjo dan Saut Situmorang yang dilaporkan ke Bareskrim Polri dan di saat yang bersamaan KPK sedang menangani kasus e-KTP, kemudian teror terhadap Agus Rahardjo dan Laode M. Syarif berupa diletakannya sebuah benda di depan rumahnya berupa bom molotov. Selanjutnya, teror juga terjadi kepada pegawai KPK salah satunya yaitu Novel Baswedan yang mendapatkan serangan fisik berupa siraman air keras tepat mengenai wajahnya dan mengakibatkan salah satu matanya tidak dapat berfungsi dengan baik sampai dengan saat ini. Kedua, terhadap ICAC Hong Kong upaya pelemahan justru banyak terjadi dari dalam / internal lembaga itu sendiri seperti seorang penyidik ICAC yang di penjara karena memberikan keterangan palsu terkait dirinya yang pernah mengancam seorang tersangka kasus korupsi yang sedang ditangani oleh ICAC, selanjutnya Komisioner ICAC 2007 - 2012 Timothy Tong yang terlibat dalam kasus penggelapan uang negara yang ia gunakan untuk kepentingan pribadinya.

Terkait dengan faktor yang menyebabkan terjadinya upaya pelemahan terhadap KPK Indonesia dan ICAC Hong Kong, hal itu disebabkan karena masih adanya pihakpihak yang tidak suka dengan keberadaan lembaga antikorupsi yang kemudian pihakpihak tersebut saling bekerja sama untuk melakukan upaya pelemahan terhadap lembaga antikorupsi demi tercapainya kepentingan pihak-pihak tersebut. Selain itu, faktor balas dendam terhadap lembaga antikorupsi juga terjadi dari para koruptor yang ditangkap oleh lembaga antikorupsi itu, mereka tentu menginginkan agar kinerja lembaga antikorupsi tersebut dapat semakin lemah dan berakhir dengan pembubaran. Sebenarnya upaya pelemahan terhadap lembaga antikorupsi itu dapat diminimalisir dengan adanya political will dari semua pihak terutama Kepala Negara, namun bukan berarti Kepala Negara dapat 
Perbandingan Upaya Pelemahan Terhadap Lembaga Antikorupsi Kpk Indonesia Dan Icac Hong Kong

mengintervensi kasus-kasus yang ditangani oleh lembaga antikorupsi, melainkan dengan tetap konsisten dalam mendukung penuh pemberantasan korupsi dan berani mengambil tindakan tegas terhadap siapapun yang ingin melakukan upaya pelemahan terhadap lembaga antikorupsi. 


\section{BIBLIOGRAFI}

Creswell, John. (2014). Research Design: Qualitative, quantitative and mixed methods approaches. London: Sage Publication. Google Scholar

Danil, Elwi. (2012). Korupsi: Konsep, Tindak Pidana dan Pemberantas. Jakarta: PT Raja Grapindo Persada. Google Scholar

Edy Susanto dan Labib Muttaqin. (2018). Mengkaji Serangan Balik Koruptor Terhadap KPK. Jurnal Integritas, Volume 04 Nomor 01. Google Scholar

Eryanto, Dedy. (2019, Maret 19). Mengenal Lebih Dekat Komisi Anti Korupsi Hongkong. Google Scholar

Febari, Rizki. (2015). Politik Pemberantasan Korupsi: Strategi ICAC Hong Kong dan KPK Indonesia. Jakarta: Yayasan Pustaka Obor Indonesia. Google Scholar

Hamzah, Andi. (2008). Perbandingan Pemberantasan Korupsi di Berbagai Negara. Jakarta: Sinar Grafika. Google Scholar

Harymurti, Bambang. (2012, Oktober 12). Kisah KPK Ulangi Gerakan Antikorupsi Hong Kong. Tempo.co

Indrayana, Denny. (2016). Jangan Bunuh KPK. Malang: Instrans Publishing. Google Scholar

Iskandar, Sherly. (2015, Januari 25). Dilaporkan Ke Polisi, Adnan Pandu Sebut Ini Upaya Kriminalisasi KPK. Merdeka.com.

Komisi Pemberatasan Korupsi. (2006). Memahami Untuk Membasmi: Buku Panduan Untuk Memahami Tindak Pidana Korupsi. Jakarta: KPK. Google Scholar

Manion, Melanie. (2004). Corruption by Design: Building Clean Government in Mailand China and Hong Kong. Massachussets: Harvard University Press. Google Scholar

Ramadhan, Ardito. (2021, Januari 28). Indeks Persepsi Korupsi Indonesia Pada 2020 Turun Jadi 37 Peringkat 102 Di Dunia. Kompas.com.

SCMP Reporter. (2003, April 5). Judge Jails ICAC Officer Who Made Threats To Witness. South China Morning Post. Google Scholar

SCMP Reporter. (2014, Juli 9). Timothy Tong's 'Unduly Close' Links With Mainland 'May Have Harmed ICAC. South China Morning Post.

Widjojanto, Bambang. (2017). Korupsi di Era Reformasi: Catatan Kritis BW. Malang: Intrans Publishing. Google Scholar

Widjojanto, Bambang dan Hadjar Abdul. (2020). Reformasi Dikorupsi, KPK Dihabisi. Malang: Intrans Publishing. Google Scholar

Widoyoko, Danang. (2016). Menimbang Peluang Jokowi Memberantas Korupsi: Catatan untuk Gerakan Anti Korupsi. Jurnal Integritas, Volume 02 Nomor 01. Google Scholar. 
Perbandingan Upaya Pelemahan Terhadap Lembaga Antikorupsi Kpk Indonesia Dan

First publication right:

Jurnal Syntax Fusion: Jurnal Nasional Indonesia

This article is licensed under:

(ㄱ) (1) (-) 